Int. J. Dev. Biol. 49: 969-976 (2005)

doi: $10.1387 / \mathrm{ijdb} .052024 \mathrm{sb}$

Original Article

\title{
A newly discovered oxidant defence system and its involvement in the development of Aurelia aurita (Scyphozoa, Cnidaria): reactive oxygen species and elemental iodine control medusa formation
}

\begin{abstract}
STEFAN BERKING*, NICOLE CZECH, MELANIE GERHARZ, KLAUS HERRMANN, UWE HOFFMANN, HARTMANN RAIFER, GUY SEKUL, BARBARA SIEFKER, ANDREA SOMMEREI and FRITZ VEDDER
\end{abstract}

Zoological Institute, University of Cologne, Köln, Germany

\begin{abstract}
In Aurelia aurita, applied iodine induces medusa formation (strobilation). This process also occurs when the temperature is lowered. This was found to increase oxidative stress resulting in an increased production of iodine from iodide. One polyp produces several medusae (initially termed ephyrae) starting at the polyp's oral end. The spreading of strobilation down the body column is controlled by a feedback loop: ephyra anlagen decrease the tyrosine content in adjacent polyp tissue by producing melanin from tyrosine. Endogenous tyrosine is able to remove iodine by forming iodiferous tyrosine compounds. The reduced level of tyrosine causes the ephyra-polypborder to move towards the basal end of the former polyp. We argue that an oxidant defence system may exist which makes use of iodide and tyrosine. Like other marine invertebrates, polyps of Aurelia contain iodide ions. Inevitably produced peroxides oxidise iodide into iodine. The danger to be harmed by iodine is strongly decreased by endogenous tyrosine which reacts with iodine to form iodiferous tyrosine compounds including thyroxin. Both substances together, iodide and tyrosine, form an efficient oxidant defence system which shields the tissue against damage by reactive oxygen species. In the course of evolution (from a species at the basis of the animal kingdom like Aurelia to a highly evolved species like man) the waste product thyroxin (indicating a high metabolic rate) has developed into a hormone which controls the metabolic rate.
\end{abstract}

KEY WORDS: iodine, metamorphosis, oxidant defence system, segmentation, thyroxin

\section{Introduction}

In Aurelia aurita strobilation consists of a segmentation of the polyp body into several pieces and the transformation of each piece into a medusa termed ephyra in this state (Fig. 1). Strobilation visibly starts just below the ring of tentacles and proceeds down the body column. Several environmental factors have been found to influence the decision to start strobilation including a reduction of the ambient temperature and altered light and nutrition (for review see Spangenberg, 1967). Paspalev (1938) observed strobilation to not become initiated in the absence of iodide ions usually present in trace amounts in seawater (between 1 and $0.1 \mu \mathrm{M}$ (Riley and Chester, 1971)). Other ions usually present in trace amounts in seawater, e.g. bromide were found to be not necessary (Silverstone et al., 1977). Spangenberg (1965, 1967, 1972) preconditioned polyps for at least one month in artificial seawater lacking iodide. When these animals were transferred back to seawater containing the normal concentration of iodide, strobilation was initiated. Spangenberg also found that the vertebrate hormone thyroxin $\left(\mathrm{T}_{4}\right)$ causes strobilation when applied at the time of temperature shift. In this case the animals were transferred from iodide free artificial seawater to seawater with only thyroxin as iodocompound (experimentally confirmed by Silverstone et al. (1977)). By means of thin layer chromatography and treatment with ${ }^{125}$-ions Spangenberg (1972) argued thyroxin to be present in Aurelia tissue. Olman and Webb (1974) failed to detect $\mathrm{T}_{4}$ in Aurelia tissue, while Black and Webb (1973) argued $\mathrm{T}_{4}$ to be present in Chrysaora tissue. Spangenberg proposed based on her findings- that strobilation in Aurelia represents the simplest system in which thyroxin is functional and is probably

Abbreviations used in this paper: ROS, reactive oxygen species; SCS, Strobilation control substance; ISCS, Strobilation control substance in the iodinated form. 
synthesised. This proposition was of particular interest because strobilation implies the metamorphosis to the adult stage and $T_{4}$ was at that time (for review see Frieden, 1981) well known to control the metamorphosis from the larva to the adult in amphibians. Silverstone et al. (1977) argued diiodtyrosine rather than thyroxin to be the responsible agent or to be similar to the agent that directly induces strobilation in Aurelia.

We argue none of these agents to play a key role in the natural way of induction of strobilation. Our data indicate that inevitably produced reactive oxygen species (ROS) and inevitably taken up iodide are the key compounds. The reactive oxygen species cause the production of elemental iodine from iodide. lodine induces strobilation by iodination of a still unknown target. We suggest the control of strobilation to have evolved out of a more basal mechanism: the removal of reactive oxygen species from the tissue.

\section{Results}

In polyps kept at normal conditions iodocompounds do not induce strobilation but elemental iodine does

Spangenberg (1965) and others (e.g. Silverstone et al., 1977) were able to cause polyps to strobilate only when they had been preconditioned by keeping them in artificial seawater free of iodide ions for at least one month. After this period the animals started to strobilate by application of potassium iodide, or various organic iodocompounds. We confirm this finding (Table 1). When unconditioned polyps (i.e. polyps kept in seawater containing the usual trace amounts of iodide) were treated in the same way strobilation did not start (Table 1). It is obvious that a preconditioning can not be the natural way of how strobilation is induced. Therewith, none of the organic iodocompounds tested including thyroxin $\left(T_{4}\right)$, triiodothyronine $\left(T_{3}\right)$, diiodotyrosine (DIT) and monoiodotyrosine (MIT) (not shown) are convincing candidates for the natural inducer.

Unconditioned polyps i.e. polyps kept for several month in seawater containing the natural amount of iodide become initiated to strobilate by application of elemental iodine or hydrogen peroxide for 24 hours (Table 2). A concentration of $1 \mathrm{nM}$ was found to be effective. We suggest iodine to be naturally involved in the induction of strobilation as will be outlined below. In the two mentioned experiments (Tables 1,2) temperature was kept constant at $20^{\circ} \mathrm{C}$.

In this and in the experiments shown in the following only a fraction of the animals of variable size was found to start strobilation due to an inducing treatment. From batch to batch and in

\section{TABLE 1}

POLYPS KEPT IN ARTIFICIAL IODIDE-FREE SEAWATER STROBILATE FOLLOWING TREATMENT WITH IODOCOMPOUNDS

\begin{tabular}{|c|c|c|c|}
\hline $\begin{array}{l}\text { Pre-treatment } \\
\text { (two months, } 20^{\circ} \mathrm{C} \text { ) }\end{array}$ & $\begin{array}{c}\text { Treatment } \\
\left(24 \text { hours, } 20^{\circ} \mathrm{C}\right)\end{array}$ & $\begin{array}{l}\text { Number of polyps } \\
\text { treated }\end{array}$ & $\begin{array}{l}\text { Percent of strobilating animals } \\
\text { on } 10^{\text {th }} \text { day }\end{array}$ \\
\hline seawater I-free & $100 \mu \mathrm{M} \mathrm{KI}$ & 60 & 71 \\
\hline seawater l-free & $100 \mu \mathrm{M} \mathrm{T}_{3}$ & 60 & 40 \\
\hline seawater I-free & seawater $(\leq 1 \mu \mathrm{M} \mathrm{KI})$ & 60 & 58 \\
\hline seawater I-free & seawater I-free & 60 & 5 \\
\hline seawater & $100 \mu \mathrm{M} \mathrm{KI}$ & 24 & 0 \\
\hline seawater & $100 \mu \mathrm{M} \mathrm{T}_{4}$ & 24 & 0 \\
\hline seawater & $100 \mu \mathrm{M} \mathrm{T}_{3}$ & 24 & 0 \\
\hline
\end{tabular}

particular in the course of the year strong differences in the efficiency of induction were observed. It appears that the switch which finally causes strobilation includes at least two components, an external one which we argue to result in a raise of the internal concentration of iodine and an internal one which includes the availability of the target to be iodinated and the processes which follow that step.

\section{Temperature reduction causes strobilation via oxidative stress resulting in enhanced iodide to iodine oxidation}

Strobilation was found to be initiated by reducing the temperature (Kroiher et al., 2000). Polyps kept at $20^{\circ} \mathrm{C}$ for a long time do not strobilate. In order to test whether the absolute temperature at the onset or at the end is decisive we reared polyps at $30^{\circ} \mathrm{C}$ for five weeks and then transferred them back to $20^{\circ} \mathrm{C}$. We found strobilation to be initiated efficiently in these animals, while those maintained (for additional two weeks) at $30^{\circ} \mathrm{C}$ remained in the polyp state (Table 3). This indicates that decreasing the temperature induces strobilation. There is no fixed threshold temperature which has to be reached in order to cause the onset of strobilation.

\section{TABLE 2}

\section{ELEMENTAL IODINE AND HYDROGEN PEROXIDE INDUCE STROBILATION IN POLYPS KEPT AT 20ㄷ IN ARTIFICIAL SEAWATER CONTAINING IODIDE}

\begin{tabular}{cccc}
$\begin{array}{c}\text { Treatment with } \\
\text { elemental } \\
\text { iodine }\left(\mathrm{KI} \mathrm{I}_{2}\right) \mathbf{n M}\end{array}$ & $\begin{array}{c}\text { Treatment with } \\
\text { hydrogen } \\
\text { peroxide } \mathbf{n M}\end{array}$ & $\begin{array}{c}\text { Number of polyps } \\
\text { treated }\end{array}$ & $\begin{array}{c}\text { Percent of } \\
\text { strobilating } \\
\text { animals }\end{array}$ \\
\hline 1 & - & 50 & 64 \\
0.1 & - & 58 & 9 \\
- & 1 & 52 & 50 \\
- & 0.1 & 50 & 0 \\
\hline
\end{tabular}

This finding argues against the possibility that a certain compound of the inducing pathway is activated / inactivated at a certain threshold temperature.

In a second experiment polyps were reared at a low and a high density, respectively (Table 4). Half of the animals were kept at $20^{\circ} \mathrm{C}$ and half were transferred to $12^{\circ} \mathrm{C}$. During the whole experiment the culture medium was not changed. After about four weeks only polyps kept at the low density at $12^{\circ} \mathrm{C}$ were found to strobilate efficiently confirming our result that temperature reduction initiates strobilation. Polyps kept at a high density at $12^{\circ} \mathrm{C}$ did almost not strobilate. There are two possible causes for that result: The polyps either produce and enrich compounds which (unspecifically) antagonise induction or the polyps have depleted their surroundings by substances they need for the onset of strobilation. The latter was found to be true: Strobilation started when the medium was enriched by iodide ions. This result indicates: strobilation in a dense culture kept at $12^{\circ} \mathrm{C}$ was not antagonised by self-produced compounds which antagonise induction but rather because the polyps and their surroundings got depleted of iodide. Table 1 shows that polyps kept in iodide-free seawater become induced to strobilate when iodide is added. Animals kept in normal i.e. iodide containing seawater do not become induced by the application of iodide. Based on this we propose that temperature reduction increases ROS production. At a low polyp density the produced iodine finally induces strobilation. At a high polyp density the quantity of iodide in the surroundings is limiting. Induction does not take place, rather 
Fig. 1. Strobilation in Aurelia aurita. (A) Polyp. (B) Young strobila. The tissue between two constrictions develops into an ephyra, i.e. a young medusa. (C) Late strobila. Ephyrae ready to detach are coloured due to produced melanin while the polypoid tissue remains uncoloured. Note the already developed tentacles of the polyp. (D) Young strobila treated with $100 \mu M$ D-penicillamine. The ephyra anlagen develop mixed structures. From oral to base: normal ephyra, ephyra with reduced lappets, with an elongated rhopalium (sense organ) in the centre. Segment with polyp tentacles bearing a statolith at the tip (rhopalium rudiment), small polyp. (E) Treatment of a young strobilae with $1 \mathrm{mM}$ D-penicillamine blocked the further proceeding of strobilation and caused each already formed ephyra anlagen to transform into a polyp. (F) Segments liberated from a D-penicillamine treated strobila. Base: the originally most apical positioned one has developed into an almost normal ephyra. The following two show with decreasing tendency ephyra and with increasing tendency polyp features. Bar, $500 \mu \mathrm{m}$.

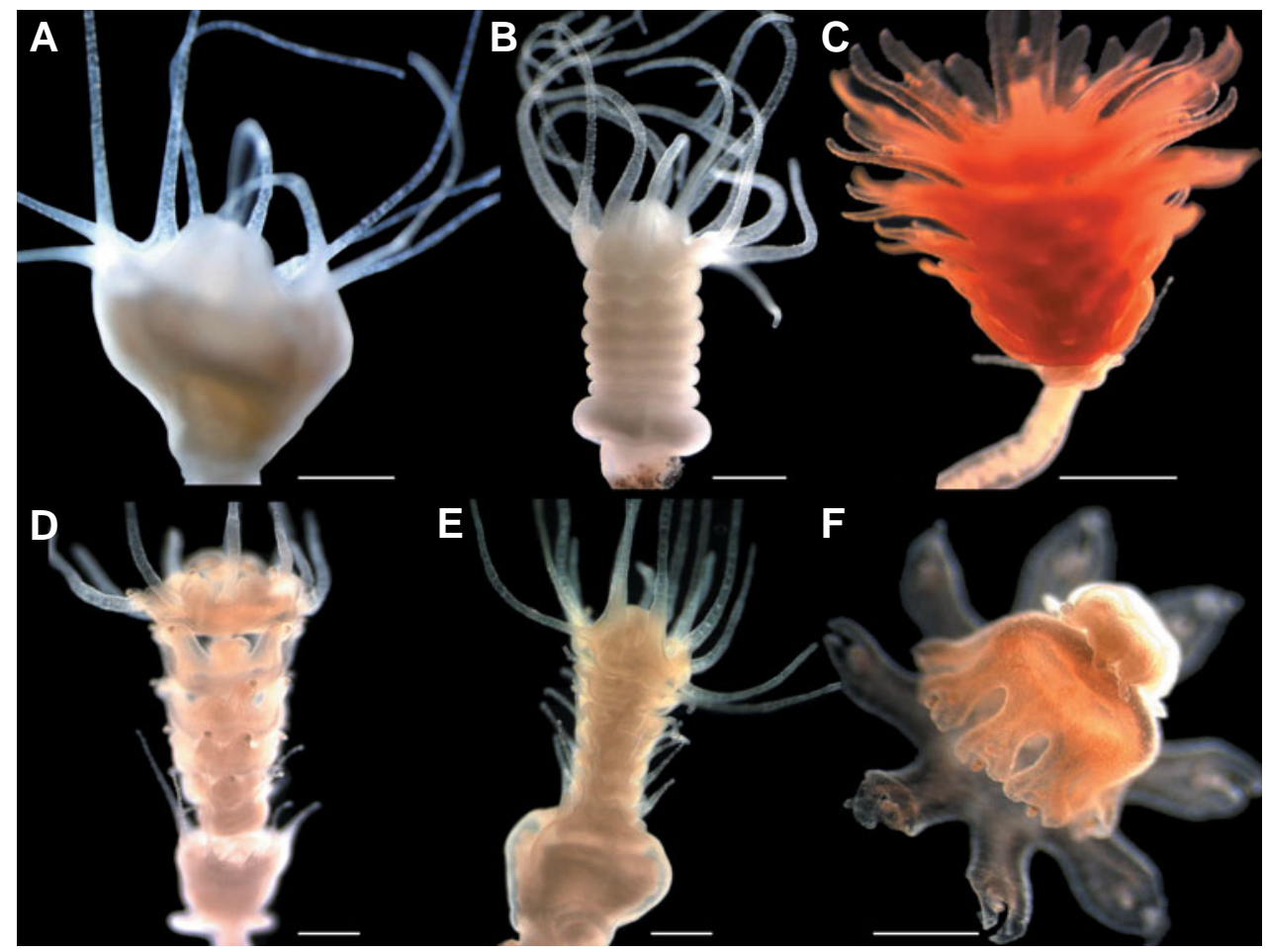

reactive oxygen species become enriched. We would like to stress that an increased level of ROS does not initiate strobilation directly. ROS act by generating elemental iodine from iodide. lodine is the inducing agent. Taken together, the experiments indicate that temperature reduction causes strobilation via oxidative stress resulting in enhanced iodide to iodine oxidation.

\section{Tyrosine antagonises induction and progression of strobila- tion}

Based on the proposition that iodocompounds like thyroxin (Spangenberg, 1967) or diiodotyrosine (Silverstone et al., 1977) induce strobilation one expects the production of these compounds and, therewith strobilation to be induced when tyrosine is added to the culture medium of polyps. Just the opposite was found: a concentration of $10 \mu \mathrm{M}$ tyrosine applied to polyps kept at a reduced temperature antagonised the induction of strobilation (Table 5). Tyrosine also antagonises the spreading of strobilation down the body column (Table 6 ). A concentration of $3 \mu \mathrm{M}$ delays proceeding, $30 \mu \mathrm{M}$ blocks it completely. Untreated controls develop into normal ephyrae. The treated strobilae ( $30 \mu \mathrm{M}$ tyrosine) did not continue the transformation of ephyra anlagen into fully developed ephyrae and also did not start to transform their polyp head (tentacles and hypostome) into the respective ephyra organs. Further, the already existing ephyra anlagen did not accumulate the ephyra specific reddish brown colour. When the animals were transferred to fresh seawater without tyrosine the process of strobilation and the differentiation of polyp into ephyra tissue restarted. When strobilae were treated for three days with $100 \mu \mathrm{M}$ tyrosine about two third of the animals did not resume strobilation following the transfer to fresh seawater. The ring folds of young ephyra anlagen smoothed out and the tissue in between developed into polyp tissue. Ephyra anlagen which had already developed small lappets were also respecified to the polyp state and developed polyp tentacles, as it was observed following treatment with tyrosinase inhibitors (see below and cf. Fig. 1). Taken together, applied tyrosine the precursor of the various iodocompounds does not stimulate but rather antagonises strobilation even when applied in trace amounts.

\section{Control of melanin production from tyrosine plays a role in control of spreading of strobilation}

From a mass culture induced to strobilate, strobilae of various developmental stages were collected and analysed for their tyrosine content (Table 7). The strobilae had a volume of between 1 and $2 \mu \mathrm{l}$. The youngest strobilae analysed displayed polypoid tissue and one ephyra anlage only. The oldest displayed all ephyra anlagen possible and the basal polypoid part bore short polyp tentacles. These strobilae did not contain fully developed ephyrae, rather the oldest ephyra anlagen were only faintly reddish-brown coloured and lappets started to develop. By application of HPLC and mass spectroscopy we found the youngest strobilae to contain a mean of $56 \mathrm{ng}$ tyrosine per animal which calculates to a concentration of between 150 and $300 \mu \mathrm{M}$. In the oldest strobilae analysed the concentration had decreased by more than one third. In this study we were also able to confirm the finding of Spangenberg (1972) who detected MIT, DIT and $T_{4}$ in

\section{TABLE 3}

\section{TEMPERATURE REDUCTION CAUSES STROBILATION IN POLYPS KEPT IN ARTIFICIAL SEAWATER CONTAINING IODIDE}

\begin{tabular}{ccc} 
Temperature shift & $\begin{array}{c}\text { Number of polyps } \\
\text { treated }\end{array}$ & $\begin{array}{c}\text { Percent of strobilating } \\
\text { animals }\end{array}$ \\
\hline $30^{\circ} \mathrm{C}-30^{\circ} \mathrm{C}$ & 50 & 0 \\
$30^{\circ} \mathrm{C}-20^{\circ} \mathrm{C}$ & 50 & 96 \\
\hline
\end{tabular}


Fig. 2. Induction of strobilation and spreading of strobilation down the body column. (1) lodide ions taken up from the seawater are (2) oxidised by inevitably generated reactive oxygen species (ROS). (3) Most of the iodine produced reacts with tyrosine giving rise to iodiferous tyrosines including monoiodotyrosine (MIT), diiodtyrosine (DIT) and thyroxin $\left(T_{4}\right)$ which leave the animal. Temperature reduction increases the availability of ROS and therewith iodine production. Due to that, iodine is not completely used up for iodination of tyrosine, rather some of the iodine is used to iodinate a hypothetical strobilation control substance (SCS) giving rise to the iodinated form of this substance (ISCS). Both, polyp tissue and ephyra tissue maintain their state by respective positive feed back loops once the state is established. (4) ISCS interferes with the polyp specific feed back loop and therewith antagonises

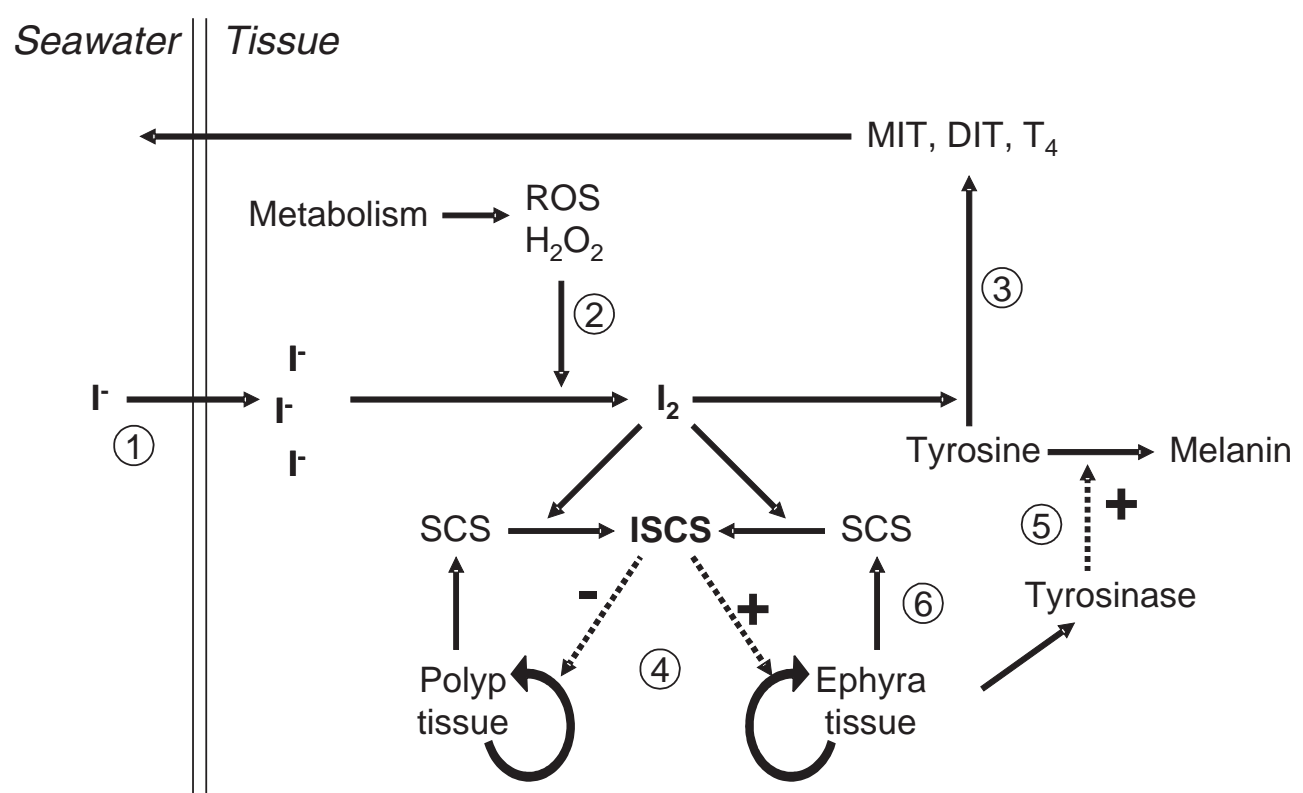

(-) polyp specific gene expression and induces (+) the onset of the ephyra specific feed back loop and therewith stimulates the generation of ephyra specific gene expression: ISCS causes the onset of strobilation, i.e. it causes the animal to leave the polyp state and to enter the ephyra state. (5) In ephyra tissue a tyrosinase becomes active which causes (+) melanin production from tyrosine thus decreasing the concentration of tyrosine in ephyra tissue. Tyrosine is able to spread in the tissue. Thus, the concentration of tyrosine decreases in polyp tissue adjacent to ephyra tissue. This results in the spreading of strobilation down the body column (cf. Fig. 3). (6) At least early steps of ephyra development depend on SCS produced by ephyra tissue.

tissue homogenate of Aurelia (not shown).

Old ephyra anlagen and fully developed ephyrae display a strong reddish-brown colour. There is a sharp colour border between the last ephyra and the basal part of the strobila which remains in the polypoid state (Fig. 1). Various authors argued this colour to be melanin. However melanin is difficult to characterise. It can not be extracted with organic solvents and it has no defined structure and spectrum. The strongest argument for the presence of melanin may be that inhibitors of tyrosinase, the enzyme which catalyses melanin production out of tyrosine, antagonise the colour production efficiently (see below).

We tested several compounds (D-penicillamine (3,3-dimethylD-cysteine), caffeic acid (3,4- dihydroxycinnamic acid) and phenylthiourea (not shown)), which can be argued to prevent melanin production out of tyrosine and therewith prevent a reduction of the tissue's tyrosine content. D-penicillamine is particularly well suited to complex $\mathrm{Cu}^{2+}$-ions. As far as we know, in all species yet tested tyrosinase activity is copper-dependent. Caffeic acid and phe-

TABLE 4

\section{TEMPERATURE REDUCTION CAUSES ENHANCED PRODUCTION OF REACTIVE OXYGEN SPECIES WHICH OXIDISE IODIDE INTO IODINE}

\begin{tabular}{cccccc}
$\begin{array}{c}\text { Temperature } \\
\text { shift }\end{array}$ & $\begin{array}{c}\text { No. animals per } \\
\text { well / No. wells }\end{array}$ & $\begin{array}{c}\text { Density } \\
\text { (animals } \\
\text { per ml) }\end{array}$ & $\begin{array}{c}\text { Percent wells containing strobilae at } \\
\text { day 26 }\end{array}$ & $\begin{array}{c}\text { day 32 } \\
\text { addition of iodide, } \\
\text { dinal concentration, } 30 \mu \mathrm{M}\end{array}$ \\
\hline $20^{\circ} \mathrm{C}$ to $12^{\circ} \mathrm{C}$ & $1 / 24$ & 0.5 & 25 & $75^{*}$ & $79^{*}$ \\
$20^{\circ} \mathrm{C}$ to $12^{\circ} \mathrm{C}$ & $3 / 21$ & 3 & 0 & 10 & 57 \\
$20^{\circ} \mathrm{C}$ to $20^{\circ} \mathrm{C}$ & $1 / 24$ & 0.5 & 0 & 0 & 0 \\
$20^{\circ} \mathrm{C}$ to $20^{\circ} \mathrm{C}$ & $3 / 19$ & 3 & 0 & 0 & 0 \\
\hline
\end{tabular}

${ }^{*}$ no iodide treatment. At day 33 all animals transferred to $20^{\circ} \mathrm{C}$. nylthiourea antagonise melanin production by competing tyrosine at tyrosinases (for review see Zoellner, 1999). We found all these compounds to block the proceeding of strobilation and to prevent the anlagen to develop the reddish-brown colour (Table 6). We would like to emphasise that the agents applied influence the tyrosine content in the tissue in quite different ways. With respect to D-penicillamine the existing anlagen did not develop typical ephyra structures, rather they developed into polyps (Fig. 1) as it was observed following tyrosine treatment (see above). Anlagen which started to develop some time before the onset of treatment developed a compromise between lappets (typical for ephyrae) and tentacles (typical for polyps) as had been described by Hadzi (1909) and Thiel (1963): the proximal part looks like an ephyra lappet while the distal part looks like a polyp tentacle which, however, bears a rhopalium rudiment including a statolith at its tip. Based on these findings we argue that (1) in developing ephyrae the former polyp's tyrosine is used up to produce melanin. (2) Melanin production is restricted to ephyra tissue. (3) When the tyrosine content is hindered to decrease or is increased artificially strobilation does not proceed and ephyra anlagen do not continue their development. They may even regress to the polyp state.

\section{Discussion}

\section{Induction of strobilation}

So far, the only agent found to induce strobilation in natural seawater is elemental iodine. A treatment of polyps with hydrogen peroxide is essentially the same as a treatment with iodine because seawater contains iodide and hydrogen peroxide oxidises this iodide into iodine. Strobilation was also found to be induced after a transfer to sterile dishes. This may result from persistent reactive oxygen species used for sterilisation (Herrmann et al., 2003). Thus, also in this case iodine appears to be the decisive 


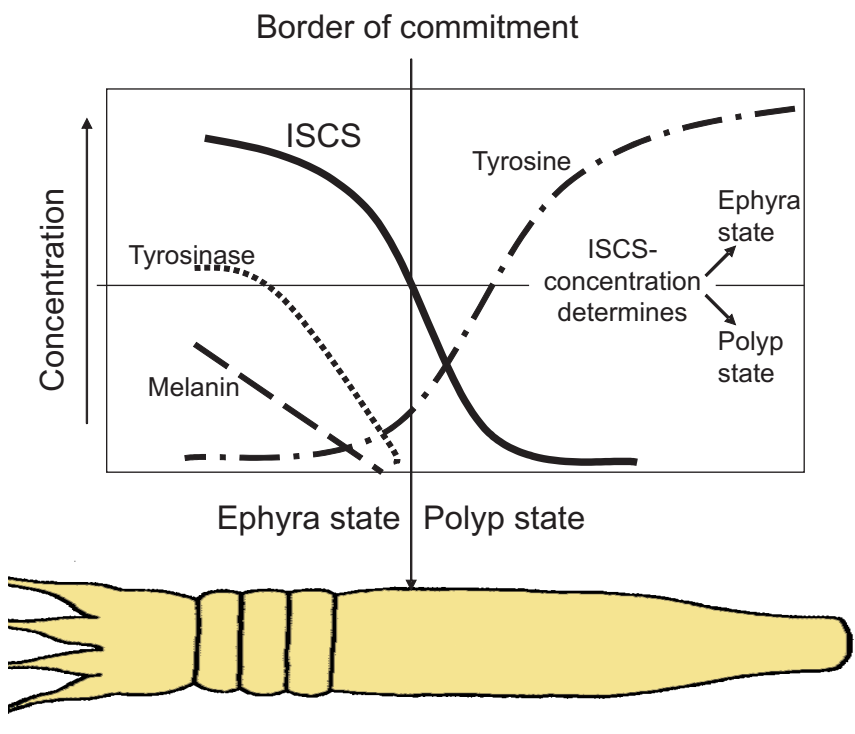

Fig. 3. Spreading of strobilation down the body column. A hypothetical strobilation control substance, termed SCS, can become iodinated to form ISCS. Where the concentration of ISCS surpasses a certain threshold the tissue leaves the polyp state and enters the ephyra state. Iodination of SCS is controlled in the following way: Produced reactive oxygen species (ROS) cause the oxidation of iodide into elemental iodine. Tyrosine and SCS compete for the generated iodine. In polyp tissue the concentration of tyrosine is so high that only small amounts of SCS become iodinated. In ephyra tissue a tyrosinase becomes active which depletes the tissue of tyrosine by forming melanin. Due to the reduced level of tyrosine an increased amount of SCS becomes iodinated. Tyrosine spreads by diffusion. This reduces the level of tyrosine in polyp tissue adjacent to ephyra tissue and at the same time increases the concentration of ISCS in that very tissue. Therewith, in polyp tissue adjacent to ephyra tissue the concentration of ISCS increases. When the concentration surpasses a certain threshold, polyp tissue transforms into ephyra tissue (cf. Fig. 2). Therewith, the ephyra-polyp-border moves towards the basal end of the former polyp. The movement ends before reaching the basal disc possibly due to too low a level of SCS.

agent. We propose elemental iodine to be the natural inducing agent (Fig. 2): lodide ions are taken up from the surroundings into the tissue (Olman and Webb,1974) and become oxidised into elemental iodine by inevitably produced hydrogen peroxides and other reactive oxygen species (ROS). Among others, a hypothetical strobilation control substance (SCS) becomes iodinated termed in this state ISCS - which initiates strobilation when present in sufficient amounts.

lodine reacts particularly well with phenols including tyrosine and tyrosine moieties of polypeptides. Free tyrosine was found to be present in Aurelia in large amounts and iodinated tyrosines including MIT, DIT, $\mathrm{T}_{4}$ have been found in tissue of Aurelia (Spangenberg, 1972). These compounds do not induce strobilation. Applied tyrosine, the precursor of all these compounds, was found to antagonise induction. In accordance with detailed studies in various cnidarians (Schlichter etal., 1986, Apte etal., 1996), we suggest also in Aurelia tyrosine to be taken up from the surroundings and to be enriched against a concentration gradient. We propose the tissue's tyrosine to stabilise the polyp state by competing with the hypothetical strobilation control substance
(SCS) (and other targets) for iodine. Only in case the iodine production exceeds a certain threshold or the tyrosine level is sufficiently reduced, the hypothetical iodinated strobilation control substance (ISCS) accumulates to a level which induces strobilation (Fig. 2).

The natural way to induce strobilation in Aurelia is a reduction of the ambient temperature. Under experimental conditions strobilation was found to start after three to four weeks in case iodide is present in the surroundings (Paspalev, 1938, Spangenberg, 1965). Strobilation is not controlled by a temperature sensitive member of the control chain which functions like a switch operating at a fixed temperature. Obviously, it is the gradual reduction of temperature which somehow causes the induction. We argue temperature reduction to cause an increased oxidation of iodide into iodine. The increased level of iodine progressively reduces the concentration of the tissue's tyrosine by iodination. Finally, the strobilation control substance (SCS) is so insufficiently shielded against iodination that the threshold level of the iodinated form of SCS, ISCS, is reached. When this happens strobilation is initiated (Fig. 2). The argument is that temperature reduction decreases the iodide concentration in the tissue and in the surroundings: we found that only animals kept at a low density and low temperature strobilate. Animals kept at a high density and low temperature do (almost) not strobilate but start strobilation immediately when iodide is added. It appears that in these animals the concentration

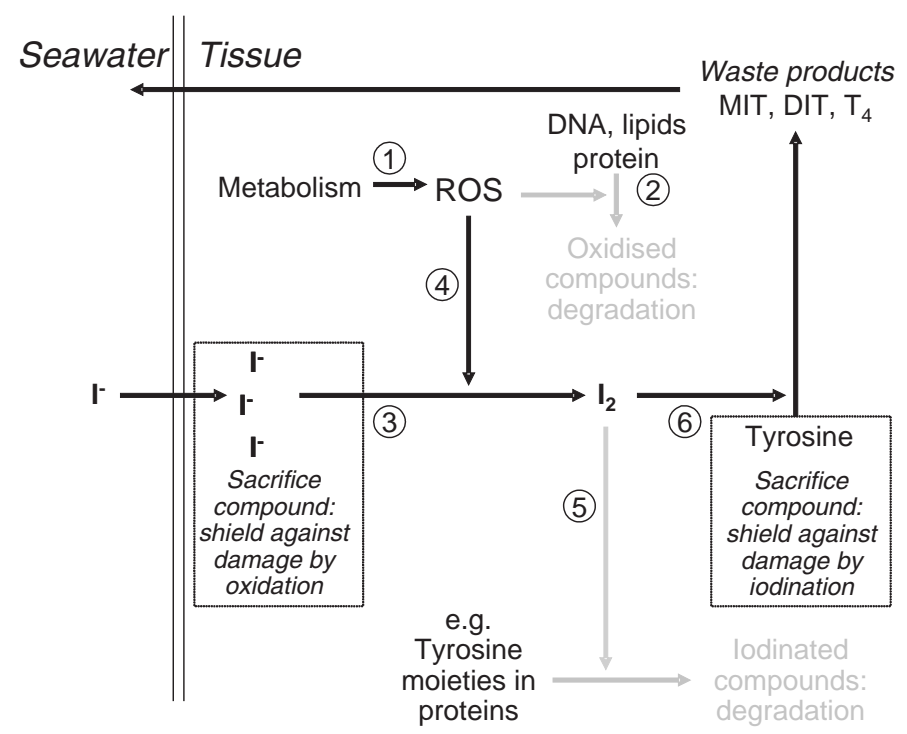

Fig. 4. Hypothetical iodine-tyrosine-oxidant defence system (IY-System) of marine organisms. In marine organisms inevitably produced reactive oxygen species (ROS) (1) can damage (2) DNA, protein and lipid components of cells. (3) Seawater contains trace amounts of iodide ions which inevitably are taken up by or even are enriched in cells. These iodide ions shield cell components against damage by oxidation because ROS oxidise (4) iodide to iodine and become therewith inactivated. lodine reacts particularly well with phenols including tyrosine moieties in (5) proteins and (6) free tyrosine giving rise to iodiferous proteins, monoiodotyrosine (MIT), diodotyrosine (DIT) and thyroxin $\left(T_{4}\right)$. A high cellular concentration of tyrosine shields proteins and other compounds effectively against iodination. The iodotyrosines can permeate membranes and therewith leave the cells and the organism. This oxidant defence system may exist in various marine organisms including bacteria, plants and animals. 
of iodide was too low to produce sufficient amounts of ISCS. In the tissue of the polyps and in the polyps' surroundings ROS are accumulated. These ROS by themselves do not cause strobilation, rather, the produced iodine does when iodide ions are added.

This conclusion allows to understand why polyps kept for weeks in the absence of iodide do not strobilate but become induced when transferred to normal seawater (cf. Table 1).

\section{Progression of strobilation}

Strobilation starts just below the polyp's ring of tentacles and proceeds down the body like a wave with a speed of roughly $1 \mathrm{~mm}$ per day (Kroiher et al., 2000). The process becomes visible in a successive formation of ring folds. The tissue between two ring folds develops into a medusa, termed ephyra at this stage. The process of strobilation can be divided into two parts: metamorphosis of the tissue from the polyp state to the ephyra state and segmentation of the body into pieces which develop into separate organisms.

\section{TABLE 5}

\section{TYROSINE ANTAGONISES INDUCTION OF STROBILATION IN POLYPS KEPT IN ARTIFICIAL SEAWATER CONTAINING IODIDE WHEN TRANSFERRED FROM $20^{\circ} \mathrm{C}$ TO $15^{\circ} \mathrm{C}$}

\begin{tabular}{ccc}
$\begin{array}{c}\text { Tyrosine }(\mu \mathrm{M}) \text { applied at the time } \\
\text { of temperature reduction }\end{array}$ & Number of animals treated & $\begin{array}{c}\text { Percent of strobilating } \\
\text { animals }\end{array}$ \\
\hline 0 & 24 & 54 \\
10 & 24 & 25 \\
30 & 24 & 4 \\
\hline
\end{tabular}

The medium including tyrosine was renewed every second day.

A spatial differential ROS production is not responsible for defining the site of the onset of strobilation. This follows from the observation that strobilation always starts at the same site irrespective of the type of induction, including induction by temperature reduction, treatment with hydrogen peroxide or iodine. Possibly the concentration of the SCS and/or other components in the signal transduction pathway is maximal at the site where induction starts. Strobilation ends before reaching the basal disc. Some tissue remains in the polyp state and regenerates into a complete polyp. The speed of strobilation decreases in a gradual manner (Kroiher et al., 2000). Thus, SCS (or certain other components in the signal transduction pathway) may form a concentration gradient reaching the lowest level in the basal disc. From batch to batch and in the course of the year the efficiency of induction was found to be different. Further, small asexually produced polyps and polyps regenerated from the basal part of a strobila which remains in the polyp state at the end of strobilation can not become induced to strobilate for several weeks. It appears that the concentration of SCS (or certain other components in the signal transduction pathway) does not only vary in space but also in time.

The following model for the spreading of strobilation is largely based on four observations: (1) applied tyrosine and (2) applied inhibitors of a tyrosinase antagonise the spreading of strobilation. (3) The tyrosine content of the tissue reduces during spreading of strobilation. (4) A tyrosinase is active in ephyra tissue only. Based on these, we propose the following (Figs. 3,4): Strobilation becomes initiated when and where the iodinated form of the hypothetical strobilation control substance (ISCS) surpasses a certain threshold. Spreading of strobilation down the body column is proposed to be essentially the same as induction, i.e. strobilation takes place where ISCS surpasses the threshold. In polyp tissue, endogenous tyrosine (including other compounds which can be iodinated) maintains the polyp state by competing with SCS for produced iodine. We suggest in polyp tissue close to ephyra tissue the tyrosine concentration to be reduced in such a way that the critical ISCS concentration is reached. In detail: exclusively in ephyra tissue a tyrosinase is active which uses up a large part of the tissue's tyrosine to produce melanin. (Other pathways which reduce the tyrosine concentration may contribute). Melanin is much less able to take up iodine than tyrosine is. Tyrosine present in polyp tissue in high concentrations is able to spread to some extent within the tissue. Therewith, polyp tissue adjacent to ephyra tissue becomes depleted of tyrosine, which reduces the shielding of SCS by tyrosine against iodination. (We will not exclude that also ISCS spreads to some extent.) Thus, in polyp tissue adjacent to ephyra tissue the concentration of ISCS rises by an increased iodination of SCS and by gain via diffusion. This results in ISCS surpassing the threshold concentration in polyp tissue adjacent to ephyra tissue which causes that very polyp tissue to transform into ephyra tissue (Figs. 3,4). The spreading of strobilation down the body column is therewith controlled by a feedback loop: ephyra anlagen decrease the tyrosine-shield in adjacent polyp tissue by producing melanin from tyrosine.

A treatment with tyrosine or D-penicillamine causes ephyra anlagen to develop back into polyp tissue. Thus, ISCS (and / or related compounds) appears to be not only necessary for induction, but also for the initial steps of ephyra development and the maintenance of the ephyra state. Further, ISCS must be produced continuously during early ephyra development and being lost from the tissue continuously. ISCS is expected to show a turnover

Mitochondria inevitably produce ROS which damage cell components by oxidation

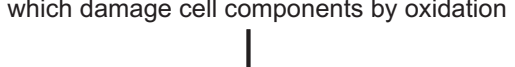

Evolutionary constraint:

development of oxidant defence systems

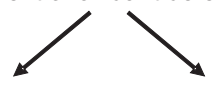

ROS oxidise Ascorbate, Tocopherol, GSH, offered as "sacrifice compounds"

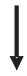

Oxidised compounds are waste products, some are recycled

IY-System: In marine organisms ROS oxidise iodide to iodine: damages cell components by iodination

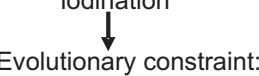

development of shield against iodination

Tyrosine offered as "sacrifice compound" $\downarrow$

lodinated compounds are waste products

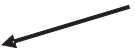

Some got new function in evolution

In Aurelia: (hypothetical) ISCS: controls strobilation

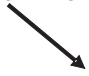

In vertebrates: Original waste product thyroxin, produced in tissue of high metabolic rate, acquires new function as hormone: controls metabolic rate

Fig. 5. Hypothetical evolution of oxidant defence systems and hypothetical evolution of thyroxin and the iodinated strobilation control substance (ISCS) out of waste products. 
TABLE 6

\begin{tabular}{|c|c|c|c|c|c|c|c|c|}
\hline \multirow[t]{2}{*}{$\begin{array}{l}\text { Compound } \\
\text { added }\end{array}$} & \multirow[t]{2}{*}{$\begin{array}{c}\text { Final } \\
\text { concentration } \\
\mu \mathrm{M}\end{array}$} & \multirow[t]{2}{*}{$\begin{array}{c}\text { Number of } \\
\text { animals treated }\end{array}$} & \multicolumn{2}{|c|}{$\begin{array}{c}\text { Mean number of ephyra } \\
\text { anlagen }\end{array}$} & \multicolumn{2}{|c|}{$\begin{array}{c}\text { Number of animals with } \mathrm{n} \\
\text { new ephyra anlagen after } \\
\text { one day }\end{array}$} & \multirow[t]{2}{*}{$\begin{array}{l}\text { Existing ephyra } \\
\text { anlagen develop reddish } \\
\text { brown colour }\end{array}$} & \multirow[t]{2}{*}{$\begin{array}{l}\text { Development of } \\
\text { new ephyrae anlagen } \\
\text { proceeds }\end{array}$} \\
\hline & & & initially & finally & $\mathrm{n} \leq 2$ & $n>2$ & & \\
\hline \multirow{3}{*}{ Tyrosine } & 0 & 24 & 1.8 & 4.5 & 10 & 14 & ++ & ++ \\
\hline & 3 & 24 & 2.1 & 3.9 & 21 & $3^{\star \star *}$ & $(+)$ & $(+)$ \\
\hline & 0 & 6 & 2.3 & 4.3 & 0 & 6 & ++ & ++ \\
\hline \multirow[t]{2}{*}{ Tyrosine } & 10 & 6 & 1.3 & 1.3 & 6 & $0^{* * *}$ & - & - \\
\hline & 0 & 6 & 2.2 & 9.1 & 0 & 6 & ++ & ++ \\
\hline D-Penicillamine & 100 & 6 & 2.7 & 11.2 & 0 & 6 & + & + \\
\hline \multirow[t]{2}{*}{ D-Penicillamine } & 1000 & 6 & 2.0 & 4.1 & $6^{*}$ & $0^{* \star *}$ & - & $-*$ \\
\hline & 0 & 6 & 1.2 & 4.7 & 0 & 6 & + & ++ \\
\hline Caffeic acid & 25 & 6 & 1.2 & 2.5 & 5 & $1^{* * *}$ & $(+)$ & $(+)$ \\
\hline Caffeic acid & 100 & 6 & 1.3 & $0.8^{* *}$ & 6 & $0^{\star \star *}$ & - & - \\
\hline
\end{tabular}

The number of new ephyra anlagen in D-penicillamine treated animals was counted 4 days after the onset of treatment. $\left(^{\star}\right)$ The new ephyra anlagen generally developed into polyps (cf. Fig. 1). $\left(^{\star \star}\right)$ Some ephyra anlagen developed back into polyp tissue. $\left.{ }^{* \star *}\right)$ Significance between treated animals and respective control animals was tested by means of the FisherYates Test $(p<0.05)$

rate of less than one day. (At present we ignore the possibility that only a certain fraction of the animal's cells is involved in this decision process.)

\section{lodide and tyrosine function as an oxidant defence system}

It looks rather strange to propose reactive oxygen species and elemental iodine to be key elements of a developmental control. One may ask how this could have been evolved. We would like to propose that the control of strobilation by means of these agents has evolved out of a more basal mechanism, an oxidant defence system.

Organisms inevitably produce hazardous hydrogen peroxides and other reactive oxygen species (ROS) which can interact with DNA, protein and lipid components of cells leading to cell damage (Figs. 4,5). Oxidant defences fall into two categories: enzymatic and non-enzymatic. The enzymatic defence includes peroxidases and catalases. Non-enzymatic defence includes small molecules such as $\alpha$-tocopherol, ascorbate and glutathione. We suggest Aurelia to contain a yet not described (probably nonenzymatic) oxidant defence system: iodide together with tyrosine.

Aurelia like other marine organisms inevitably takes up iodide ions present in seawater in trace amounts. Without the help of enzymes, peroxides oxidise iodide into elemental iodine. lodine rapidly reacts in particular with phenols including free tyrosine and tyrosine moieties in proteins at positions 3' and 5' of the ring. Even trace amounts of thyroxin are formed. This reaction does not depend on enzymes, either. Thus, one may expect Aurelia to make efforts to remove iodide from the tissue in order to avoid the extremely reactive and dangerous iodine. Just the opposite was observed. Olman and Webb (1974) found iodide to be enriched against a concentration gradient. Two further observations are of interest here. Spangenberg (1972) found iodinated tyrosine compounds in polyps of Aurelia. We found large amounts of tyrosine in polyp and strobila tissue. On the basis of these findings we suggest in Aurelia a two-component oxidant defence system to exist which acts in the following way (Fig. 4). (1) The inevitably produced peroxides oxidise the taken up iodide to elemental iodine. (2) lodine rapidly reacts with phenols, in particular with the free amino acid tyrosine to produce iodotyrosines. lodotyrosines are largely membrane permeable and therefore can leave the tissue and the animal.

ROS including peroxides have a broad range of potential damage. Elemental iodine has a much smaller range. Thus, in the presence of sufficient amounts of iodide and substances which can function as "sacrifice compounds" like tyrosine the potential damage of ROS is strongly reduced. We suggest in Aurelia and other marine organisms a iodine-tyrosine oxidant defence system (IY-system) to exist with the function to protect the tissue from becoming damaged by permanently produced peroxides and against an unspecific iodination of e.g. tyrosine moieties in polypeptides. The system may also make use of tyrosine moieties in special proteins including ancestors of thyreoglobuline.

Compared to other oxidant defence systems, e.g. the glutathionsystem (Epp et al., 1983, Meister and Anderson, 1983), in the IYsystem the substrate to be oxidised is not recycled but is rather taken up from the surroundings and is discarded in the oxidised state. The protection by the system depends on the constant delivery of iodide. It thus may be restricted to marine organisms including marine animals, plants, fungi and bacteria. Due to the independence from enzymes the system is fast, efficient and robust. An external application of $1 \mathrm{nM}$ iodine and hydrogen peroxide, respectively, were found to cause strobilation. Thus, the

TABLE 7

\section{TYROSINE CONTENT IN STROBILAE}

Tissue analysed ng Tyrosine per individual \pm S.D.

\begin{tabular}{lc} 
Strobila with one ephyra anlage & $56.1 \pm 3.7$ \\
Strobila, half polyp half ephyra anlagen & $41.3 \pm 5.1$ \\
Strobila with last ephyra anlage formed & $34.4 \pm 12.6$ \\
\hline
\end{tabular}


IY-system appears to keep the internal level of ROS including peroxides at a very low concentration. In Aurelia kept in iodidefree seawater reactive oxygen species accumulate, indicating the importance of the IY-system for oxidant defence and indicating the relative unimportance of other systems (Table 1).

The protection of proteins and other compounds against iodination can be suspected to be incomplete and the iodinated compounds can be supposed to have lost their original function. In the course of evolution some of them may have acquired a new function. We suggest ISCS to have evolved from such an accident (Figs. 4,5). Experiments with the hydroid Hydractinia echinata show that elemental iodine induces metamorphosis from the larva to the polyp state (published elsewhere). The obtained doseresponse-curve displays an optimum (at about $15 \mu \mathrm{M}$ ) as observed for other inducing agents (for review see Berking, 1998). lodide ions failed to induce metamorphosis. When larvae were treated with $\mathrm{CsCl}$ for three hours (one of the most reliable inducing treatments) and tyrosine was added one hour following the inducing treatment the efficiency of induction was found to be strongly reduced. A temperature decrease does not cause metamorphosis but an increase does (Kroiher et al., 1992). It appears that these animals also use ROS and iodide for the control of developmental processes. We suggest a compound functionally related to ISCS to have evolved from a compound which has lost its original function by iodination.

We propose marine organisms to have been constrained during evolution to offer sacrifice compounds which become iodinated and which therewith protect essential compounds from becoming iodinated. In case tyrosine is used as a sacrifice compound the local internal concentration of the iodotyrosines including thyroxin strongly correlates with the metabolic activity of that very tissue. In vertebrates thyroxin is involved in the control of the metabolic activity. It is tempting to speculate that in the course of evolution the original waste product thyroxin, in particular produced in tissue with a high metabolic rate, has acquired a new function as a hormone which controls the metabolic rate. (Fig. 5).

\section{Materials and Methods}

Polyps of Aurelia aurita (collected form the North Sea at Luc sur Mer, Normandy, France) were mass cultured in artificial seawater (1000 mosmol, $\mathrm{pH} 8.2,20^{\circ} \mathrm{C}$ ). lodide free artificial seawater was prepared according to Spangenberg (1965). If not otherwise stated, throughout an experiment the polyps were kept separately in dishes with $1.0 \mathrm{ml}$ of seawater at $20^{\circ} \mathrm{C}$. The polyps were not fed during the experiments.

Strobilae of various developmental stages were collected form a mass culture subjected to $12^{\circ} \mathrm{C}$ for three weeks. Probes of 10 animals were disintegrated mechanically and treated with TCA on ice for 15 minutes. Following centrifugation (15.000 rpm, $10 \mathrm{~min})$ the supernatant was subjected to chromatography (HPLC RP C18, in 0.1\% TFA, acetonitrile / water, from $0 \%$ acetonitrile to $84 \%$ acetonitrile within 10 minutes) applying a UV and a fluorescence detector (for tyrosine: EX: 280nm, EM: $310 \mathrm{~nm}$ ). The fractions which by means of pure standard compounds were argued to contain tyrosine and iodotyrosines, respectively, were subjected to masspectroscopy (LCQ, iontrap, Finnigan). The analysis included the determination of $\mathrm{m} / \mathrm{z}$-values of the compounds contained and of their respective fragments following controlled collisions. The area of the tyrosine peak was used to determine the tissue content of tyrosine. Statistics. When necessary, in the tables the significant differences (Fisher-Exact-Test, $\mathrm{P}<0.05$ ) are indicated by an asterisk.

\section{References}

APTE, S., KHOURY, F., ROTH, W. and SCHLICHTER, D. (1996). Transport of amino acids into freshly isolated cells from a sea anemone. Endocytobiosis Cell Res. 11: 129-146.

BERKING, S. (1998). Hydrozoa metamorphosis and pattern formation. Curr. Top. Dev. Biol. 38: 81-131.

BLACK, R. and WEBB, K. (1973). Metabolism of iodine-131 in relation to strobilation of Chrysaora quinquecirrha (Scyphozoa). Comp. Biochem. Physiol. 45A: 10231029.

EPP, O., LADENSTEIN, R. and WEDEL, A. (1983). The refined structure of the selenoenzyme Glutathion-peroxidase at $0.2-\mathrm{nm}$ resolution. Eur. J. Biochem. 133: $51-69$

FRIEDEN, E. (1981). The dual role of thyroid hormones in vertebrate development and calorigenesis. In Metamorphosis, 2nd ed. (Eds. Gilbert, L.E. and Frieden, E.) Plenum Press, pp 545-563.

HADZI, J. (1909). Rückgängig gemachte Entwicklung einer Scyphomeduse. Zool. Anz. 54: 94-100.

HERRMANN, K., SIEFKER, B. and BERKING, S. (2003). Sterile polystyrene culture dishes induce transformation of polyps into medusae in Aurelia aurita (Scyphozoa, Cnidaria). Methods in Cell Science 25: 125-136.

KROIHER, M., WALTHER, M. and BERKING, S. (1992). Heat shock as inducer of metamorphosis in marine invertebrates. Roux's Arch. Dev. Biol. 201: 169-172.

KROIHER, M., SIEFKER, B. and BERKING, S. (2000). Induction of segmentation in polyps of Aurelia aurita (Cnidaria, Scyphozoa) into medusae and formation of mirror-image medusa anlagen. Int. J. Dev. Biol. 44: 485-490.

MEISTER, A. and ANDERSON, M.E. (1983). Glutathione. Ann. Rev. Biochem. 52: 711-760.

OLMAN, J.E. and WEBB, K.L. (1974). Metabolism of iodine-131 in relation to strobilation of Aurelia aurita(Scyphozoa). J. Exp. Mar. Biol. Ecol. 16: 113-122.

PASPALEV, G.V. (1938). Über die Entwicklung von Rhizostoma pulmo. Agass. Arb. Biol. Meerest. Varna 7: 1-25.

RILEY, J.P. and CHESTER, R. (1971). Introduction to marine chemistry. Academic Press New York.

SCHLICHTER, D., BAJORAT, K.H., BUCK, M., ECKES, P., GUTKNECHT, D., KRAUS, P., KRISCH, H. (1986). Epidermal nutrition of sea anemones by absorption of organic compounds dissolved in the oceans. Zoologische Beiträge N. F. 30: 29-47.

SILVERSTONE, M., TOSTENSON, T.R. and CUTRESS, C.E. (1977). The effect of iodide and various iodocompounds on initiation of strobilation in Aurelia. Gen. Comp. Endocrinol. 32: 108-113.

SPANGENBERG, D.B. (1965). A study of strobilation in Aurelia aurita under controlled conditions. J. Exp. Zool. 160: 1-10.

SPANGENBERG, D.B. (1967). lodine induction of metamorphosis in Aurelia. J. Exp. Zool. 165: 441-449.

SPANGENBERG D.B. (1972). Thyroxine induced metamorphosis in Aurelia. J. Exp. Zool. 178: 183-194.

THIEL, H. (1963). Untersuchungen über die Entstehung abnormer Scyphistomae, Strobilae und Ephyrae von Aurelia auritaLAM. und ihre theoretische Bedeutung. Zool. Jb. Anat. 81: 311-358.

ZOELLNER, H. (1999). Handbook of Enzyme inhibitors. 3rd edition Weinheim, New York, Chichester, Brisbane, Singapore, Toronto, WILEYVCH.

Received: May 2005

Reviewed by Referees: June 2005

Modified by Authors and Accepted for Publication: August 2005 